\section{FAZL-I-OMAR RESEARCH INSTITUTE, QADIAN}

$\mathrm{B}$ OTH in the East and the West, the advancement of knowledge has in the past owed much to the benefactions of religious communities. A remarkable sign of the recognition of the important part which science must play in the India of the future is shown by the decision of the leader of the Ahmadyya community, Hazrat Hkalifatul Masil, to devote a generous part of its funds to the foundation of a research institute. This community is responsible already for a number of educational institutions, including the Talmial Islam College, but its leader now considers the time to be ripe for a further development. The new research institute, the Fazl-i-Omar Research Institute, Qadian, is being opened at a time when India is undergoing a scientific renaissance, and private benefactions have their part to play in making this a success.

The Institute was opened on April 19 by Sir Shanti Bhatnagar, and in an address of welcome, the director, Dr. Abdul Ahmad, gave a short account of its objectives. It is not proposed that the Institute should be devoted entirely to research of an industrial character, since it is clearly recognized that if this is to meet with success it must be based upon fundamental academic research. Situated as it is in an area where agriculture forms the main industry, it is natural that the programme of research on the fundamental side should show a marked biochemical bias, while the industrial research is concerned with the utilization of agricultural products such as vegetable oils. To facilitate the work, the Institute has attached to it a small experimental farm. Dr. Ahmad's address shows that the Institute will have the most up-todate equipment; but it does not appear to have been fully recognized that of even greater importance is the calibre of the scientific staff which will be necessary if this equipment is to be fruitfully employed.

For more than six years, Indian men of science have been cut off from all outside contacts, and although no one can doubt the rich store of latent ability, this will take time to develop. Throughout the length and breadth of India new research institutes have been opened or are projected, and if these are to be successful they will require leaders of outstanding quality with highly qualified staffs. These are not at present to be found in India, and it is improbable in view of the general dearth of such men in other countries that external recruitment will be possible. It cannot therefore be anticipated that the contribution of this new Institute, whether it be to fundamental science or to the development of industries, will be large for a number of years.

In the brief address delivered by Sir Shanti Bhatnagar before formally opening the Institute, he rightly stressed the point that there is no longer any conflict between science and religion. He emphasized that the approach of science and of the scientific method to industry must be based upon fundamental research, and warned his listeners to beware of the utilitarian type of mind which success in the field of applied science can produce.

We extend a hearty welcome to this new Institute and we do not doubt that in due time it will exert a profound influence on the development of science in northern India.

\title{
SOCIAL PROBLEMS OF RE-SETTLEMENT
}

$\mathrm{T}$ HE major problem of re-settlement in Britain, and all the implications of the Government schemes for dealing with some four million ex-Service men and women in civilian life, are the subject of two broadsheets issued by Political and Economic Planning. It is doubtful whether either the Forces or the general public appreciate the sheer magnitude of this operation, coupled with inter-industrial transfers, or the many difficulties, particularly psychological, which are likely to arise. The first of these broadsheets, No. 238, "The Disabled Ex-Serviceman", deals with one limited aspect of re-settlement : the question of how the community can best fulfil its obligation to the men and women who have suffered lasting disability as a result of their war service. The main reason for treating this subject separately is that the official schemes appeared to be yielding too high a proportion of failures; but even in this broadsheet it is pointed out that in many respects the distinction between the fit and the disabled is artificial. Both alike need not only the service of efficient re-settlement machinery, but also sympathetic help and advice from officials who like and understand their fellows. Fundamentally, re-settlement is an exercise in the art of treating people as free human beings, not arbitrarily classified units; and the second broadsheet, No. 239, "Re-settlement", is largely confined to a survey of the outstanding needs and problems involved in re-settlement, and a description of the ways in which the Government, reinforced by voluntary effort, proposes to tackle them.

Describing first the Government scheme under the Disabled Persons (Employment) Act, 1941, and the work of the Disabled Persons (Employment) Corporation, the National Advisory Council and the District Advisory Committee, the broadsheet cites several instances of disabled men being offered or directed to unsuitable work by disablement rehabilitation officers. Only through a welfare 'followup' were these men eventually placed in satisfactory jobs, and the broadsheet accordingly stresses the need for adequate co-operation between the hospital authorities and the Ministry of Labour, and for welfare follow-up in every case. Much of the criticism in the broadsheet centres on the disablement re. habilitation officer.

The disablement rehabilitation officer is in fact the pivot of the Government's occupational re-settlement scheme, and in view of this evidence that a wrong type of person is frequently being chosen for this work, the broadsheet suggests that, instead of being limited to regular Civil servants from one or a few depart. ments, the field of recruitment should be widened to include, for example, ex-Servicemen who have been doing similar work during the War and who appreciate their fellow-servicemen's point of view, and labour officers from ordnance factories. Another proposal for improving the operation of the schemes is greater attention to the psychological needs of injured men in the early stages of hospital treatment.

The universal follow-up by social welfare workers already mentioned as desirable would in practice mean continuing the work of the field officers and hospital almoners, visiting the disabled men regularly and keeping in touch with the disablement rehabili. tation officer until the man is thoroughly settled at 